ROCZNIKI TEOLOGICZNE

Volume LXV, issue 10 - 2018

English version

DOI: http://dx.doi.org/10.18290/rt.2018.65.10-9en

\author{
REV. WITOLD JEDYNAK
}

MAREK A. MOTYKA

\title{
SELF-DECLARATION OF RELIGIOUSNESS AND THIS VARIABLE'S CONNECTIONS WITH INDICATIONS OF PSYCHOACTIVE SUBSTANCE USE: DATA FROM EMPIRICAL STUDIES (N=2273)
}

\begin{abstract}
A b s tract. A steady increase in the use of intoxicants is being confirmed by empirical studies. One of the factors conducive to drug initiation is the rejection of moral norms associated with religious beliefs. The article presents the relations established between the youth's declared religiousness and their statements on psychoactive drugs and using them. The data were collected through questionnaire surveys carried out on a randomly selected sample of high school students from the Podkarpackie region $(n=2273)$. The research results suggest that the process of secularisation and relativisation observed among the youth, particularly in the sphere of morality, may weaken critical attitudes towards psychoactive substances, both those legally allowed and those prohibited by law. Moreover, the links between the declared religiousness and such variables as: time spent on the Internet, acquaintances who are drug users, being raised by a single parent or both parents as well as the frequency of conversations between respondents and their parents were established. The connections between these variables are statistically significant, so it can be concluded that these distinguished variables influence the diversity in religiousness stated by participants and consequently the liberalisation of the youth's attitudes towards drugs.
\end{abstract}

Keywords: religiousness; morality; youth; drugs; addiction.

Observers and researchers of the narcotics phenomenon have noted that there is a systematic increase in the number of adolescents who use psychoactive substances in Poland. The youth's statements towards this data are

Rev. Dr. Hab. Witold Jedynak, Professor at UR, director of the Institute of Sociology, Faculty of Sociology and History, University of Rzeszów, correspondence address: Al. Rejtana 16 C, 35-959 Rzeszów; e-mail: vox321 @interia.pl

Dr. Marek A. MotyKa is an assistant professor at the Institute of Sociology, Faculty of Sociology and History, University of Rzeszów, correspondence address: Al. Rejtana 16 C, 35-959 Rzeszów,e-mail: mmotyka@ur.edu.pl 
presently conditioned by many social elements. One of them is undoubtedly the religiousness of the young generation and their religious morality. Many years of sociological research confirms that Poles are one of the most religious societies in Europe. It is really interesting to mark the relationships between religiosity among the youth and those who use psychoactive substances.

The authors of the following work, based on data obtained in the framework of empirical studies, have undertaken to tie the relationship of religiousness as declared by youth and their statements towards psychoactive substances and whether they use them. The research was done in the Podkarpackie region, which, in comparison to other voivodships, has one of the highest indicators of religiousness in Poland. The decided majority of youth living in the Podkarpackie voivodship declared to have faith in God, they are tied to the Catholic faith and regularly participate in religious services. The researcher was interested in determining to what degree the religiousness of the youth living in Podkarpackie has an effect on their moral choices, particularly their stance towards using psychoactive elements. The goal of the research seems to be very interesting, since the Catholic faith requires that its faithful follow moral and religious norms in their daily lives.

\section{RELIGIOUSNESS AND ITS CRITERIA}

Religiosity is expressed in attitudes and behaviors in which man refers to transcendental reality. It is a subjective response to faith-based expectations which are most often established by religious institutions. Religiousness is usually institutionalized and is oriented towards the values and norms adopted by the Church or smaller religious groups. Therefore, it is also connected with one's social and cultural life. ${ }^{1}$

Religious values, norms and patterns of behavior are transmitted in the process of socialization, and the decisive role is played by members of the immediate family and all religious institutions. In sociological research, the framework of religious institutions is more clearly expressed in the external signs of this religion. Institutional religion allows us to determine the extent to which individuals can be considered religious from the perspective of the expectations of a certain religious institution. The religious criteria

\footnotetext{
${ }^{1}$ Cf. Edward JARMoch, "Religijność indywidualna Polaków," in Kościót i religijność Polaków 1945-1999, ed. Witold Zdaniewicz, Tadeusz Zembrzuski (Warszawa: Instytut Statystyki Kościoła Katolickiego SAC, 2000), 385.
} 
established by the Church and religion, implemented in the course of religious socialization, allow us to empirically describe (measure) the religiousness of the followers of a given religion. ${ }^{2}$

Empirical research on religiousness is a complex process that is constantly evolving. In the early sociological phases, research on religiousness focused the attention of researchers on the external aspects of religiousness. The most important criterion was people's religious practices, especially participating in Sunday Mass. People's level of religiousness was determined by their participation in community religious rites, their frequency of participating in the sacraments, their public expression of the faith, reading religious press, and involvement in Church initiatives, including active participation in Church organizations. The respondents who are more often involved in activities that are required by religious institutions are considered to be more religious people.

Newer sociological studies take into account the fact that religiosity is not always expressed by institutionalized and standardized patterns of behavior, which can only be the results of social control, habits, family traditions and customs. Currently, it is assumed that religiousness is manifested by one's faith, life and actions. This kind of religious expression is shown not only through religious practices, but also in other religious activities and in accepting stances towards set values, norms and symbols established by Church institutions. In addition to participating in religious worship, one's individual belief and religiously motivated morality are also included. ${ }^{3}$

\section{RELIGION AND MORALITY}

Socio-cultural changes have influenced the transformation of religiosity and morality in modern man. At present, one can observe a deviation from the institutionalized forms of morality shaped by religious institutions, especially Christian Churches. According to A. Giddens, traditional rules and norms have ceased to be binding in contemporary society, and individuals have to choose among an unending number of new proposals. These changes

\footnotetext{
${ }^{2}$ Cf. Janusz MARIAŃSKI, Kościót w spoteczeństwie przemystowym (Warszawa: Instytut Wydawniczy PAX, 1983), 18.

${ }^{3}$ Ibidem, 19-21; Janusz MARIAŃSKI, Religia w spoteczeństwie ponowoczesnym. Studium socjologiczne (Warszawa: Oficyna Naukowa, 2010), 101-106; 179-185.
} 
concern fundamental values that create one's personal, family and professional life. ${ }^{4}$

Attitudes and social behavior are influenced by secularization processes, socio-cultural pluralisation and the privatization of religion. These influence the lives of individuals and clearly weaken bonds between religion and morality. ${ }^{5}$ Religion, which for centuries influenced the moral system of regulating human behavior, for many is now more and more often becoming a type of doctrine that does not really affect the lives of individuals or has a very limited effect on people. A man who rejects the religious criteria of what is morally good and evil becomes the highest judge who simply evaluates his own behavior. ${ }^{6}$

The rejection of traditional moral norms based on religion and not finding a satisfying alternative can lead to a moral vacuum or moral anomy, resulting in loss, rebellion or apathy. Proponents of religious morality believe that the cause of social pathologies is usually the weakening or severance of ties between religion and morality. Ethics is not enough for leading a good life, people also need higher existential support in God. Religion and morality cannot be separated. Without religion, ethical orders have no binding force. As a consequence, man becomes the only instance who, based on subjective reasons, decides on what is good and what is bad. ${ }^{7}$

On the other hand, opponents of religious morality claim that morality should not be subject to religious commands and pressure from external authorities, because these violate its autonomy. According to them, religion does not just seem to be necessary for justifying moral norms, but it may even pose a threat to the independence of individuals who want to decide about their own actions. Therefore, the young generation should be raised in reference to the universal principles of humanism, common to both believers and unbelievers. According to this concept, morality has a non-religious dimension, because it concerns the relationship between one man and another man, and not the relationship between a man and God. Morality, therefore,

\footnotetext{
${ }^{4}$ Anthony GidDENS, Socjologia (Warszawa: Wydawnictwo Naukowe PWN, 2006), 198-199.

${ }^{5}$ Rafał BogusZEwsKi, “(Nie)religijna moralność katolików w Polsce,” Zeszyty Naukowe KUL no. 1(57) (2014): 123-124.

${ }^{6}$ Janusz MARIAŃSKI, Przemiany moralności polskich maturzystów w latach 1994-2000. Studium socjologiczne, (Lublin: Wydawnictwo KUL, 2011), 416-417.

${ }^{7}$ Piotr JAROSZYŃSKI, "Etyka i religia—opozycja czy dopełnienie?" in U źródet tożsamości kultury europejskiej, ed. Tomasz Rakowski (Lublin: Lubelska Szkoła Filozofii Chrześcijańskiej KUL, 1994), 111-112; Vittorio Possenti, Religia i życie publiczne. Chrześcijaństwo w dobie ponowożytnej (Warszawa: Instytut Wydawniczy PAX, 2005), 151.
} 
should not be associated with religion, because both believers and unbelievers live in every society. Unbelieving people have their lay, humanistic morality, which is not related to any one specific religious system. ${ }^{8}$

An indirect solution seems to be the concept that there is a relationship between religiousness and a believer's moral behaviors. For example, the Catholic religion is not only a source of moral brakes, but positively affects the attitudes and behaviors of believers, proposing mercy and good works. This does not mean, however, that there is a necessary relationship between the two dimensions of human existence, which are religiousness and morality. Religion does not have exclusive rights to formulating and justifying moral directives that bind all people. ${ }^{9}$

Many years of sociological research shows that in Poland's society, the Catholic Church's influence on people's morality is weakening, and thus the scope of the influence of religion as a determinant of the behavior of individuals, groups, and communities is diminishing. Adult Poles are less and less affected by the need to justify their behavior based on religious morality. They usually construct an individual moral system for themselves that is a consequence of their subjective judgments. The strong attachment of adult Poles to religion and religiousness does not mean that they behave in accord with the norms of Church morality. Even those who declare themselves to be regularly practicing believers are not necessarily guided by the criteria of good and evil set by religion in moral matters. ${ }^{10}$

An even greater dischord between religiousness and morality is found in the young generation of Poles. Youth more and more often perceive morality and religion as two separate, unconnected realities. Therefore, the youth also declare moral relativism and the selective treatment of religious morality. Young people usually choose the norms and values that are appropriate (convenient) for them in a specific situation from among the system of

\footnotetext{
${ }^{8}$ Cf. Peter L. Berger, Pytanie o wiarę. Sceptyczna zachęta do chrześcijaństwa (Warszawa: Instytut Wydawniczy PAX, 2007); ZIELIŃSKI, Michał. Religia a moralność (Toruń: Wydawnictwo Adam Marszałek, 2000), 88-80; Wojciech PAWLIK, "Tożsamość religijna a etyka niezależna-społeczny wymiar dyskursu," in Tożsamości religijne w społeczeństwie polskim. Socjologiczne studium przypadków, ed. Maria Libiszowska-Żółtkowska (Warszawa: Wydawnictwo Delfin, 2009), 119-135.

${ }^{9}$ Cf. Maria OssowsKa, O człowieku, moralności i nauce: miscellanea (Warszawa: Państwowe Wydawnictwo Naukowe, 1983), 445-452, 523; Janusz MARIAŃSKI, "Kontrowersje wokół relacji religii i moralności-tożsamość czy rozdział," Universitas Gedanensis no 1-2 (2009): 3334; 41-42; Mariusz ZEMŁo, "Socjologia moralności Marii Ossowskiej i Janusza Mariańskiego. Analiza porównawcza," Roczniki Nauk Spotecznych no 2, (2015): 147-150.

${ }^{10}$ Cf. Boguszewski, “(Nie)religijna moralność katolików w Polsce,” 135-137.
} 
religious morality. ${ }^{11}$ The individualization of morality, and in particular its separation from religion, points to the explicit secularization tendencies present among young Poles. ${ }^{12}$

\section{USING PSYCHOACTIVE SUBSTANCES}

The results of drug addiction statistics from the last two decades confirm the unidentified dynamics of attitudes towards illegal drug, and at the same time their increased popularity shows that youth use drugs for hedonistic and recreational purposes. In 2017, the United Nations Office on Drugs and Crime (UNODC) in a cyclically updated report on global drug trends presented the latest data on the extent of this phenomenon. The presented results confirm an almost constant increase in the number of drug users over the last decade, from 203 million users in 2008 to 255 million people in the world who declared they tried drugs in recent surveys. ${ }^{13}$

Data collected by the European Monitoring Center for Drugs and Drug Addiction (EMCDDA) confirm the constant dynamics of the European drug market, including the emergence of the supply of online psychoactive drugs in recent years and an increase in new types of drugs, the so-called "afterburners." 14 An alarming phenomenon is the increasing use of various substances among drug users and the high popularity of marijuana used among young Europeans aged $15-16 .^{15}$

\footnotetext{
${ }^{11}$ Cf. Janusz MaRIAŃSKI, Młodzież między tradycją i ponowoczesnościa. Wartości moralne w świadomości maturzystów (Lublin: Redakcja Wydawnictw KUL, 1995), 336-345; Sławomir H. ZARĘBA, Dynamika świadomości religijno-moralnej młodzieży $w$ warunkach przemian ustrojowych w Polsce (1988-1998) (Warszawa: Zakład Wydawnictw Statystycznych, 2003), 279; MARIAŃsKI, Przemiany moralności polskich maturzystów w latach 1994-2000, 447-448; Sławomir H. ZARĘBA, W kierunku jakiej religijności? Studia nad katolicyzmem polskiej młodzieży (Warszawa: Zakład Wydawnictw Statystycznych, 2008), 504-509.

${ }^{12}$ Cf. Mariańs Ki, Janusz. Matżeństwo i rodzina w świadomości młodzieży maturalnej. Stabilność i zmiana, (Toruń: Wydawnictwo Adam Marszałek, 2012), 93, 395; Witold JEDYNAK, "Wybrane aspekty przemian religijności i moralności młodzieży polskiej," in Czy stracone pokolenie? Młodzież i jej dylematy na początku XXI wieku, ed. Piotr Długosz, Hubert Kotarski, Witold Jedynak, (Rzeszów: Wydawnictwo Uniwersytetu Rzeszowskiego, 2014), 22-23.

${ }^{13}$ The United Nations Office On Drugs And CRime, World Drug Report 2017 (Vienna: United Nations Publication, 2017).

${ }^{14}$ European Monitoring Centre For Drugs And Drug Addiction, European Drug Report 2017: Trends and Developments (Luxembourg: Publications Office of the European Union, 2017), 19-20.

${ }^{15}$ Ibidem, 41-42.
} 
In 2016, a study "Consumption of Psychoactive Substances by Youth. Youth 2016" was carried out in Poland. A randomly chosen group of 1,724 senior year students from 82 secondary schools were selected (high schools, technical schools and vocational schools). The studies carried out show that among these Polish youth, the most widespread psychoactive substance is beer, and $74 \%$ of students declared drinking it, while other alcoholic drinks were enjoyed with great interest. In addition, $42 \%$ of respondents admitted to using marijuana, currently the most popular drug among students, $7 \%$ used amphetamines and there were lower percentages for other drugs.

Every third respondent confirmed having information about the sources of psychoactive drug distribution, and every third person admitted that they had no difficulty in obtaining such knowledge. ${ }^{16}$ As part of these considerations, it is worth remembering that in the last recalled survey, the factor differentiating respondents, both in terms of the frequency of alcohol consumption and the use of illegal narcotics, are the religious attitudes of the young people. Students who were more involved in religious matters less frequently reported cases of binge drinking. Those who declared having a deeper faith less often indicated reaching for drugs than their peers who declared themselves to be non-believers. ${ }^{17}$

\section{THE RELATIONSHIP BETWEEN RELIGIOUSNESS AND USING PSYCHOACTIVE SUBSTANCES}

In order to show the destructive process in a person who uses psychoactive drugs, Wojciech Wanat described this addiction as a "cancer of the soul" 18 whose development promotes anhedonia, alienation, and inner emptiness, including the devaluation of principles and values. ${ }^{19}$ Artur Sroka indicates that the philosophy of hedonism promises to maximize the desire for pleasure, but people in the modern world ignore all rules and experience a "spiritual vacuum and existential misery." 20 Justyna Siemienowicz ascribes

\footnotetext{
${ }^{16}$ Por. Artur Malczewski, "Młodzież a substancje psychoaktywne," in Młodzież 2016. Raport z badania sfinansowanego przez Krajowe Biuro ds. Przeciwdziałania Narkomanii (Warszawa: Fundacja Badania Opinii Społecznej CBOS, 2016), 212-222.

${ }^{17}$ Ibidem, 209-219.

${ }^{18}$ Wojciech WANAT, Narkotyki i narkomania. Odlot donikad (Warszawa: Wydawnictwo „Iskry”, 2006), 27.

${ }^{19}$ Ibidem, 79-81.

${ }^{20}$ SROKA, Artur. Teologia narkotyku (Warszawa: Wydawnictwo „Eneteia,” 2008), 8-9.
} 
contemporary cultural with changes causing "the extinction of great spiritual traditions, in which the overriding value was the effort to work on one's personality, the process of spiritual improvement." 21

The author referred to intoxicating substances as "the prosthesis of the soul" which fills the emptiness of alienated individuals that arises after the loss of their soul. ${ }^{22}$ In their considerations, the cited authors point to the immaterial effects of using psychoactive drugs, which are undeniably related to religion and morality. However, these are more of a consequence than the reason for undertaking this type of behavior. Much more important, however, seems to be establishing the sources of the identified changes.

At the end of the nineteenth century, interesting observations were made by Emile Durkheim, who defined society as a collection of ideas, feelings, beliefs and values setting patterns of social interaction. ${ }^{23}$ The researcher believed that order and stability are maintained by integrating social equilibrium, and the key role in maintaining this is played by developed and respected behavior patterns in a given nation. ${ }^{24}$ According to E. Durkheim, the essence of maintaining homeostasis and the sense of meaning of life is fulfilled by religion and religious rites that unite a society, consolidate group traditions, and serve in the reception and initiation of community members into a collective life. Moreover, all this "serves to strengthen individuals during moments of breakdown and crises." 25 The inability to satisfy essential needs (including the need for stability, predictability, and a feeling of security) may contribute to the formation of "abnormal" or anomic states. ${ }^{26}$

At present, analogous observations are being confirmed by Mariusz Jędrzejko, which state that the ongoing civilizational and cultural changes constitute the source of the uninterrupted flow of these principles, and one of the consequences of the observed transformations is the "battle to draw people away from religion, from a moral reflection on life." ${ }^{27}$ Taking into

\footnotetext{
${ }^{21}$ Justyna SiEMiEnowicz, “Dusza pod narkozą,” Znak no 693 (2013): 9-10.

${ }^{22}$ Ibidem, 6-10.

${ }^{23}$ Cf. FERnÁNDEZ, María P.L. "El Concepto de Anomia de Durkheim y Las Aportaciones Teóricas Posteriores." Revista de Ciencias Sociales de la Universidad Iberoamericana 4, no 8 (2009): 132.

${ }^{24}$ Cf. Rouhi ZHAO, Liqun CAO, "Social Change and Anomie: A Cross-National Study," Social Forces 88, no 3 (2010): 1210.

${ }^{25}$ Jerzy SzACKI, Historia myśli socjologicznej (Warszawa: Wydawnictwo Naukowe PWN, 2007), 390.

${ }^{26}$ Cf. Osco, Buddi. "Anomie or Alienation? A Self-Exploration of the Roots of Substance Abuse.” Human Architecture: Journal of the Sociology of Self-Knowledge 2, no 1 (2003): 105.

${ }^{27}$ Mariusz Z. JĘDRZEJKo, „Zawirowany” świat ponowoczesności (Warszawa-Milanówek: Oficyna Wydawnicza ASPRAJR/Centrum Profilaktyki Społecznej, 2015), 187-201.
} 
account the above considerations, the number of occurring axioms and normative relativism may favor both the behavior previously considered immoral and the search for so-called spiritual relief in the "swirl" of the post-modern world. Psychoactive drugs, termed "the prosthesis of the soul," can be used, among others, to achieve a certain level of spiritual relief.

\section{MATERIALS AND METHODS}

This work presents the relationships identified as part of empirical studies carried out among young people between respondents' self-declared religiousness and their attitudes towards psychoactive drugs and using these substances. The presented data is the result of empirical research carried out in the 2015/16 school year, whose aim was to identify the socio-cultural determinants of the phenomenon of drug addiction in the Podkarpackie Voivodeship. The study involved youth from public high schools (secondary and technical) in the Podkarpackie region.

Selecting this age group was dictated by both developmental factors (using psychoactive drugs is one of the risky behaviors characteristic of this age group $)^{28}$ and the need to establish differences or associations in analogous youth behavior from other regions of Poland. There may be a need to take adequate actions (one of the authors of this article participates in local prevention actions). In the Podkarpackie Voivodship, the last surveys of this type were carried out in 2011, but these studies did not specify the reasons for using psychoactive drugs. They only attempted to determine the scale of the Podkarpackie youth who try drugs. ${ }^{29}$

In the process of preparing for the presented statistics, the following research questions were formulated:

-What environmental conditions are conducive to the liberalization of attitudes towards illegal drugs?

-Does the profile of the school where young people learn and their relationships with other students influence the use of drugs?

\footnotetext{
${ }^{28}$ Danuta Ponczer, Iwona Olszowy, "Styl życia młodzieży i jego wpływ na zdrowie," Pro blemy Higieny i Epidemiologii no 2 (2012): 265.

${ }^{29}$ Grzegorz GościŃsKI, Raport o narkotykach i narkomanii w Województwie Podkarpackim w 2016 roku (Rzeszów: Urząd Marszałkowski Województwa Podkarpackiego Departament Ochrony Zdrowia i Polityki Społecznej, 2017), 5; https://www.podkarpackie.pl/index.php/ zdrowie/raportyanalizy (13.06.2018).
} 
-Does the involvement of young people in learning and taking up education-related activities have an impact on access to drugs?

-What family conditions influence a youth's decision to use drugs?

-What demographic factors influence young people to use drugs?

-What economic factors influence young people to decide to use drugs?

-What cultural factors influence young people to use drugs?

-What role does popular culture play in creating a positive image of drugs?

Detailed questions and hypotheses were formulated according to the above problems, which were verified during statistical analysis. A thorough description of the conceptualization process, however, exceeds the possibilities of a scientific research article, therefore, the results of the whole study will be presented in a broader study. The presented data, however, allows us to answer questions related to some cultural determinants: is there a relationship between one's declared religiousness and a young person's attitude towards psychoactive drugs? Does the declared level of religiousness correlate with the indications of using these substances? Moreover, an attempt was made to determine the factors conditioning the indicated self-declaration of religiosity by establishing connections with the following variables: the amount of time spent on web sites, having friends who use drugs, being raised by both parents and the frequency of talks between the youth and their parents. It has been hypothesized that differences in these variables may affect the religious positions of young people.

In this study, alcohol, cigarettes and illegal narcotics were included on the list of psychoactive drugs. Estimating the influence of the above variables on smoking was also made. The religiousness of the respondents was presented as a self-declaration. When answering the question "How would you express your religiousness?" the respondents had the option of choosing one of three answers: 1) I'm a practicing believer; 2) I believe, but do not practice; 3) I'm not a believer. The given answers were compared with these outstanding variables.

A random layered sampling was used to obtain representative data. The data was taken from the Spis Szkót.pl website for the Podkarpackie Province educational institutions, which served as a sampling framework. The study area was divided into three layers (the first layer included schools from Rzeszów, the capital of the province, second were schools from cities with a population of $>20$ thousand, and third were schools from cities with a population of $<20$ thousand, including rural schools). 
In the first place, a location was randomly chosen, and then in each place, if necessary, schools were chosen. The choice of a class was dependent on the educational foundations of a given institution, and one group from each year group was selected in each school. As a result of the random sampling, 15 high schools and 12 secondary technical schools from the 19 areas of the Podkarpackie Voivodeship entered the research sample. The survey measurement was carried out on a total of 103 class divisions.

In order to obtain a response to the formulated research problems, the author constructed a questionnaire tested in the pilot measurement prior to the proper tests. As a result, surveys were collected from among nearly 2,500 respondents, which, after selection, data collected from 2,273 students were used for the analysis. The research was carried out with the approval of the Podkarpackie Board of Education, and participation in the research was voluntary. The measurements were carried out personally by the project's author (Motyka) without the teachers being present, which was supposed to help reduce the number of false answers. The collected data were coded in the IBM SPSS Statistic 20 program, and these calculations were subjected to statistical analysis. The significance of relationships between variables was determined using the chi-square test, and the results were statistically significant: $\mathrm{p}>0.001$

The Podkarpackie Voivodeship where the research was carried out is located in the southeastern part of Poland and covers an area of $17,890 \mathrm{~km}^{2}$. Ukraine is located on its eastern border, and to the south is Slovakia. The tourist industry in this region is found in the Bieszczady mountains and other cities founded by the rulers of the Piast dynasty and the Jagiellonians, where there are multicultural towns intersecting numerous trails of wooden architecture. It is a part of Poland that is much less urbanized than the central and western voivodships. ${ }^{30}$ Some researchers see this region as the place with a higher religiosity index as compared to other provinces. The inhabitants maintain customs regarded as traditional. A source of the region's cultural capital are also strong social ties (the cohesion) of residents. ${ }^{31}$ It is an environment with the highest indicators of life expectancy. ${ }^{32}$

\footnotetext{
${ }^{30}$ Andrzej SAdOwSKI, "Wschodnie województwa Rzeczypospolitej-uwarunkowania konstruowania kapitału pogranicza,” Konteksty Spoteczne no 2 (2013): 10.

${ }^{31}$ Ibidem.

${ }^{32}$ GUS, Trwanie życia w 2015 r. (Warszawa: Zakład Wydawnictw Statystycznych, 2016), 25.
} 


\section{Analysis of the Research Results}

The study involved slightly more girls, which accounted for $54 \%$ of the sample. On account of the school's profile, 53\% of high school students and $47 \%$ of technical school students participated in the survey measurement. Most of the study's participants were rural residents who accounted for $64 \%$ of the study sample. The research was to determine the scale of the use of psychoactive drugs, among others, and the following data were collected regarding their use: smoking was indicated by $23 \%$ of students, $65 \%$ confirmed that they consumed alcohol, and three out of ten (30\%) admitted to smoking marijuana. $9 \%$ of the respondents claimed that they used other drugs.

It was interesting to note that adolescents did not treat marijuana the same way as other illegal drugs (saying it was not a narcotic), which they stated during the pilot research tool. Therefore, our results present the use of this substance separately. The percentage of marijuana users and those who noted they had dealt with other drugs was not summarized, because the majority of students using cannabis confirmed at the same time that they used other illegal drugs. Therefore, after compiling data on the use of these drugs, it was agreed that $31 \%$ of students (712 people) admitted to having contact with drugs.

In the conducted research, declarations of faith and participation in religious practices were accepted as religious indicators. Respondents were given three types of answers to select from in which they had the opportunity to mark their level of religiousness. The collected data showed that the vast majority of pupils described themselves as believers (71\%), and on average, every fifth stressed that he was a "non-practicing believer" (22\%), and 7\% marked the category "non-believer." As part of the analysis of the empirical material, we attempted to find the relationship between one's selfdeclaration of religiosity and indicators showing the use of the aforementioned psychoactive drugs. The obtained results turned out to be interesting (Table 1).

Table 1. Self-declarations of religiousness and the use of psychoactive substances $(n=2273)$

\begin{tabular}{|l|l|c|c|c|l|}
\hline \multicolumn{2}{|l|}{ Self-declaration of religiousness } & Believer & $\begin{array}{l}\text { Non-practicing } \\
\text { believer }\end{array}$ & Non-believer & Significance \\
\hline $\begin{array}{l}\text { Using } \\
\text { psychoactive } \\
\text { substances }\end{array}$ & cigarettes & $16 \%$ & $37 \%$ & $43 \%$ & $\mathrm{p} \leq 0.001$ \\
\cline { 2 - 6 } & alcohol & $59 \%$ & $76 \%$ & $83 \%$ & \\
\hline
\end{tabular}




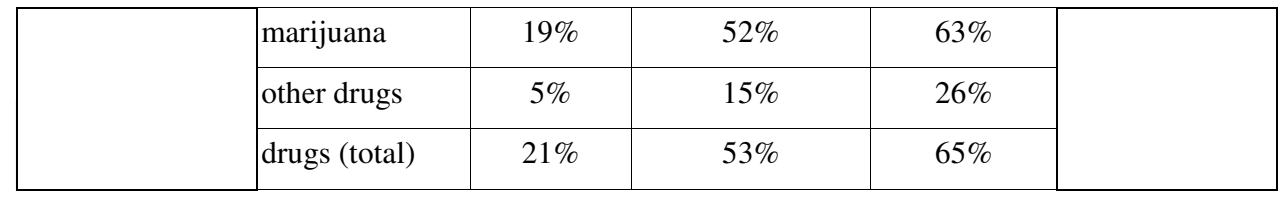

Source: own research

As can be seen in the above list, the group that claims to be "believers" has the lowest percentage of pupils confirming that they smoke cigarettes, drink alcohol, and use illegal narcotics. At the same time, the highest percentage of these types of activities have been identified among people who describe themselves as "unbelievers." The indications of the use of these substances by respondents declaring themselves to be "non-practicing believeing people" are present in the responses of the above mentioned groups. Data analysis confirmed that statistically significant relationships exist between variables.

At the same time, depending on their self-declaration of religiosity, differences in opinions about psychoactive drugs were observed among the respondents. In the measurement, these positions were established on the basis of two variables: seeing drugs in terms of the safety of these substances and opinions on whether marijuana should be legalized. In the surveyed sample group, every fifth respondent $(21 \%)$ thought that drugs were safe substances, and $41 \%$ approved of permitting cannabis to be generally used. The data were then compiled along with the respondents' self-declarations of religiosity (table 2).

Table 2. Self-declarations of religiousness / stances towards psychoactive substances $(n=2273)$

\begin{tabular}{|c|c|c|c|c|c|}
\hline \multicolumn{2}{|c|}{ Self-declarations of religiousness } & believer & $\begin{array}{c}\text { Non-practicing } \\
\text { believer }\end{array}$ & Non-believer & Significance \\
\hline \multirow{2}{*}{$\begin{array}{l}\text { Stance towards } \\
\text { illegal drugs }\end{array}$} & Drugs are safe & $14 \%$ & $37 \%$ & $37 \%$ & \multirow{2}{*}{$\mathrm{P} \leq 0.001$} \\
\hline & $\begin{array}{c}\text { Marijuana should } \\
\text { be legalized }\end{array}$ & $33 \%$ & $60 \%$ & $66 \%$ & \\
\hline
\end{tabular}

Source: own research

Our analysis of the collected empirical material confirmed that there are also statistically significant relationships between the respondents' self-declarations on religiousness and their positions on psychoactive drugs. 
Believing people are much less likely to state that drugs are safe for users, and they are much less likely to want to legalize marijuana, while in other groups these indications are twice as high. Therefore, it can be said that people who declare to be religious and practice their faith have more critical positions towards drugs than respondents who call themselves believers yet do not practice their faith, and they are also more critical than students who declare themselves to be "unbelievers."

In addition, interesting associations were found among those declaring their religiosity and other variables whose exploration was carried out within the framework of the implemented project. These were particularly the amount of time spent on online activities, having drug users in their peer group, or being raised by both parents (in so-called full families). Relationships between these variables are presented in Tables 3-6.

On the basis of the data summarized in Table 3, we concluded that with the increasing amount of time spent on the Internet, one's attitude towards religion can change; among the people who spend less than two hours a day on the Internet, eight out of ten of these peeople called themselves "believers" and only one in twenty (5\%) indicated that they were "unbelievers." Among students devoting more than 4 hours each day to the virtual reality, slightly more than half of the respondents $(57 \%)$ declared they were "believing persons," while religious indifference was stated by $12 \%$ of the group.

Table 3. Time spent on the internet / religious self-declaration $(n=2273)$

\begin{tabular}{|c|c|c|c|c|c|}
\hline \multicolumn{2}{|c|}{ Time on the Internet } & $\begin{array}{l}\text { Less than } \\
2 \text { hours/day }\end{array}$ & $\begin{array}{l}2 \text { to } \\
4 \text { hours }\end{array}$ & $\begin{array}{c}\text { Over } 4 \\
\text { Hours/day }\end{array}$ & Significance \\
\hline \multirow{4}{*}{$\begin{array}{l}\text { Self-declaration } \\
\text { of religousness }\end{array}$} & Believer & $79 \%$ & $70 \%$ & $57 \%$ & \multirow{4}{*}{$\mathrm{p} \leq 0.001$} \\
\hline & $\begin{array}{c}\text { Non-practicing } \\
\text { believer }\end{array}$ & $16 \%$ & $24 \%$ & $31 \%$ & \\
\hline & Non-Believer & $5 \%$ & $6 \%$ & $12 \%$ & \\
\hline & Total & $100 \%$ & $100 \%$ & $100 \%$ & \\
\hline
\end{tabular}

Source: own research

The research did not determine the direction of dependence, however, it seems more likely that the impact of time spent on the Internet and the statements of religious indifference by respondents seems to be an opposite relationship. 
Analogously, the relation between the self-declaration of religiosity and having friends who use illegal drugs was also determined (Table 4).

Table 4. Relationships between those using drugs and religious self-declarations $(n=2273)$

\begin{tabular}{|c|c|c|c|c|}
\hline \multicolumn{2}{|c|}{ Relationships with others who use drugs } & $\begin{array}{c}\text { I know } \\
\text { such people }\end{array}$ & $\begin{array}{c}\text { I do not know } \\
\text { them }\end{array}$ & Significance \\
\hline \multirow{3}{*}{$\begin{array}{c}\text { Self-declaration of } \\
\text { religiousness }\end{array}$} & $\begin{array}{c}\text { Neliever } \\
\text { believer }\end{array}$ & $65 \%$ & $78 \%$ & \multirow{2}{*}{$\mathrm{p} \leq 0.001$} \\
\cline { 2 - 4 } & Non-Believer & $10 \%$ & $17 \%$ & $5 \%$ \\
\cline { 2 - 4 } & Total & $100 \%$ & $100 \%$ & \\
\hline
\end{tabular}

Source: own research

Here, too, it can be noticed that there are relationships between sets of variables; among the declared "non-believering" pupils, every tenth $(10 \%)$ has friends who use substances that have the properties of illegal drugs, while two-thirds of the respondents in this group indicated they were "believers" (65\%). Among respondents who deny this type of knowledge, nearly eight in ten said they were "believers," while there are half as many people who declare themselves to be "unbelieving" among those who maintain relationships with drug using peers $(5 \%)$. Unfortunately, here too, the direction of the relationship has not been established: does knowing people who use drugs affect the indicated religious lack of ideology, or rather does being a "non-believer" favor having relationships in such an environment. The data is statistically significant; the peer environment in which respondents function may create such a relationship in the self-declared religiousness of the responses.

The last variable was to find associations with people's declared religiosity, and it concerned the family environment of the respondents. The questionnaire distributed among students asked whether they were brought up by both parents (in a full family). A broken or incomplete family is one in which one parent is absent because of death or divorce. The second important issue was how regularly students and their parents talk with each other. The obtained data were then compared to the respondents' declared religiosity (Tables 5-6). 
The analysis of the empirical material shows that there is a statistically significant relationship between being raised in a full or incomplete family and a person's religious self-declaration.

Table 5. Family status / self-declaration of religiousness $(n=2273)$

\begin{tabular}{|c|c|c|c|c|}
\hline \multicolumn{2}{|c|}{ Family status } & Full Family & $\begin{array}{c}\text { Incomplete } \\
\text { Family }\end{array}$ & Significance \\
\hline \multirow{3}{*}{$\begin{array}{c}\text { Self-declaration of } \\
\text { religiousness }\end{array}$} & Believer & $74 \%$ & $52 \%$ & \multirow{2}{*}{$\mathrm{p} \leq 0.001$} \\
\cline { 2 - 4 } & Non-practicing believer & $20 \%$ & $33 \%$ & \\
\cline { 2 - 4 } & Non-Believer & $6 \%$ & $15 \%$ & \\
\cline { 2 - 4 } & Total & $100 \%$ & $100 \%$ & \\
\hline
\end{tabular}

Source: own research

Among the pupils who said that they are being raised by both parents, almost three-fourths indicated that they are "believing" people, while only $6 \%$ were "non-believers." On the other hand, half of the students who stated they grew up in an incomplete family said they were "believers," but the percentage of "non-believers" in comparison to those who were born in a full family increased almost threefold (15\%). The obtained data are statistically significant, so we can state that being raised by both parents may be encourage by both religiousness and practicing one's faith more than growing up under the care of only one parent.

In the undertaken explorations, regular talks between parents and children (Table 6) also played an important role. An analysis of the empirical data showed that students confirming regular conversations with parents most often pointed out that they are "believing people" (82\%) and, at the same time, they are the least likely to describe themselves as non-believers $(4 \%)$. These stances are reduced as the frequency of dialogue between youth and their parents decreases, and families where there are no conversations have the lowest indications of religiosity among students. 
Table 6. Frequency of talks with parents / self-declaration of religiousness $(n=2273)$

\begin{tabular}{|c|c|c|c|c|c|c|}
\hline \multicolumn{2}{|c|}{ Frequency of talks } & Always & $\begin{array}{c}\text { Not about } \\
\text { everything }\end{array}$ & $\begin{array}{c}\text { Only when } \\
\text { they ask }\end{array}$ & Never & Statistics \\
\hline \multirow{3}{*}{$\begin{array}{c}\text { Self-declaration } \\
\text { of religiousness }\end{array}$} & Believer & $82 \%$ & $74 \%$ & $66 \%$ & $55 \%$ & \\
\cline { 2 - 6 } & $\begin{array}{c}\text { Non-practicing } \\
\text { believer }\end{array}$ & $14 \%$ & $21 \%$ & $25 \%$ & $30 \%$ & \multirow{2}{*}{$\mathrm{p} \leq 0.001$} \\
\cline { 2 - 6 } & Non-Believer & $4 \%$ & $5 \%$ & $9 \%$ & $15 \%$ & \\
\cline { 2 - 6 } & Total & $100 \%$ & $100 \%$ & $100 \%$ & $100 \%$ & \\
\hline
\end{tabular}

Source: own research

Among respondents who noticed deficiencies in their relationships with parents, 55\% consider themselves to be "believers," $30 \%$ stated that they "believe, but do not practice," while $15 \%$ stated they were religiously indifferent. The significance of the identified relationships confirms that constant parental care, exemplified by a regular interest in their child's affairs, may be a factor protecting youth against religious indifference, and as earlier analyses confirmed, it protects youth from changing their perception of risky behaviors as being easy and safe activities. This consequently stops them from undertaking decisions about risky practices, meaning the possibility of drug initiation.

Time spent on the Internet, a peer community in which drug users are present, as well as family factors are all conditions that influence undertaking risky activities, including using illegal drugs. This was found in other research measurements on drug addiction. ${ }^{33}$ It seems right to call it multidimensional, multifaceted and difficult to determine, both in terms of risk factors and those that may have factors that protect someone against taking on dangerous behaviors, both for the individual's health as well as their autonomy.

\footnotetext{
${ }^{33}$ Ram Chander Jiloha, "Social and Cultural Aspects of Drug Abuse in Adolescents," Delhi Psychiatry Journal 12, no 2 (2009): 168-169; Marek MotYKA, Jerzy T. MARCINKOwSKI, "Rola czasu spędzanego w Internecie w liberalizacji postaw wobec środków psychoaktywnych wśród uczniów przemyskich szkół gimnazjalnych," Problemy Higieny i Epidemiologii no 3 (2014): 737-743; Marek МотҮкA, "Uwarunkowania narkomanii młodzieży: zagrożenia w środowisku rodzinnym i rówieśniczym," in Zagrożenia ładu społecznego oraz bezpieczeństwa narodowego, ed. Maciej Gitling; Ireneusz Wojaczek (Przemyśl: Wydawnictwo Państwowej Wyższej Szkoły Wschodnioeuropejskiej, 2017), 3555; A. Ismail, H.B. AfFAndy, S.N. BASIR, N. Ahmad, The Internet: One of the Factors Influencing Substance Abuse, https://www.researchgate.net/publication/2692 23304 (26.01.2018).
} 


\section{INTERPRETATION OF THE RESULTS}

Comparing the data on the use of psychoactive drugs, both the legal (cigarettes and alcohol) and those subject to legal regulations (marijuana and other illegal drugs), our results expressly confirm the role of participating in religious practices as a factor protecting youth against undertaking risky behaviors. All the results listed in Table 1 showed that the "believing" group had the lowest indications of using drugs, and these people attended regular religious practices.

Establishing the above dependencies is not something new; over a century ago, E. Durkheim noted that by participating in religious beliefs, an individual is initiated into a group's life; these rituals unite a community and cultivate group traditions. ${ }^{34}$ Such an "initiation to live in a group" means the acquisition of rules respected by a particular religion, and hence it includes prohibitions imposed on the faithful; among others, this includes an oath to maintain tobacco and alcohol abstinence until one's eighteenth birthday, no alcohol during the celebrations of receiving the sacrament of First Communion, and the commandment "do not kill" which includes no harming oneself and means rejecting the use of illegal drugs.

Gathering at common rituals makes individuals feel moral bonds with the other participants of the ritual, and at the same time, this strengthens their mutual relationships by experiencing a ceremony together. It functions to unite people, including parents and children after a week's work of rushing through life, duties, going to school, etc. Cultivating tradition strengthens beliefs, while the function assigned to religious rituals strengthens an individual at difficult moments. All this plays a role in crises moments that occur at various stages of life.

The results obtained in this study confirm the observations made by E. Durkheim; the stronger the relationships of respondents with the faith, in this case regular participation in religious practices, the lower the indications of violating internal norms that are set by participating in such rituals, meaning that these young people do not use drugs, smoke or consume alcohol.

Authors of other studies also pay attention to the importance of religion as a protective factor. Eugeniusz Mitek thinks that the decline in interest in religion among drug users may be associated with an early sympathy with people who use drugs, and consequently this encourages them to use drugs. ${ }^{35}$

\footnotetext{
${ }^{34}$ Cf. SZACKI, Historia myśli socjologicznej, 390.

${ }^{35}$ Cf. Eugeniusz MiтEK, "Sympatyzowanie młodzieży z osobami zażywającymi narkotyki," Perspectiva. Legnickie Studia Teologiczno-Historyczne no 2 (2004): 174-176.
} 
Establishing relationships between the self-declaration of religiousness of respondents from the Podkarpackie Voivodeship and their having "doping" friends showed that among the respondents described as "unbelievers," only a slightly higher percentage than the "believers" confirms that they have friends who use drugs.

Persons having such doping friends actually show a somewhat lower interest in religion, which as a consequence may weaken their following moral norms, including abstinence from using psychoactive substances. However, these data require confirmation through a more detailed measurement of the role of religion and religiosity in undertaking risky behaviors.

Such research was carried out, among others, by Paulo Dalgalarrondo and coworkers among adolescents in Brazil $(\mathrm{n}=2287),{ }^{36}$ by Flavio Francisco Marsiglia and his team among American teenagers $(n=7304)^{37}$ and Ruth C. Engs and Kenneth Mullen among a group of Scottish students $(n=4065) .^{38}$ In each of the measurements carried out, the researchers distinguished a much larger number of variables determining religiousness and established the relationships between these variables and drug use among the respondents, while their declarations concerning the faith and practicing religion were one of the important variables included in these studies. High indications of religiousness and participating in religious practices have been established as determinants that definitely protect young people from using drugs.

\section{SUMMARY}

Our analysis of the results of the empirical research has shown that in the case of the surveyed youth, there is a relationship between their selfdeclarations of religiosity and their attitude towards the use of psychoactive drugs. The level of religiosity in a young person influences her or his attitudes and moral behaviors regarding the use of psychoactive drugs. People who declare themselves to be believers least often fall into the trap of

\footnotetext{
${ }^{36}$ Cf. Paulo Dalgalarrondo, Meire A. Soldera, Heleno R.C. Filho, Cleide A.M. Silva, "Religion and Drug Use by Adolescents," Revista Brasileira de Psiquiatria 26, no 2 (2004): 82-90.

${ }^{37}$ Cf. Flavio F. Marsiglia, Stephen Kulis, Tanya Nieri, Monica Parsai, "God Forbid! Substance Use Among Religious and Nonreligious Youth," American Journal of Orthopsychiatry 75, no 4 (2005): 585-598.

${ }^{38}$ Cf. Ruth C. ENGS, Kenneth Mullen, "The Effect of Religion and Religiosity on Drug Use among a Selected Sample of Post Secondary Students in Scotland," Addiction Research 7, no 2 (1999): 149-170.
} 
using psychoactive drugs, whereas the non-believers show the greatest acceptance for this type of behavior. This means that in the case of the Podkarpackie youth, there is a relationship between religiousness and their moral behavior. However, this relationship is not necessary, since some of the people who declare themselves to be believers do not accept the moral norms imposed on them by their religion.

These studies indicate that young people are undergoing secularization and relativization of moral norms, especially in the sphere of morality, which manifests itself in their weaker rejection of using psychoactive drugs. Their attitudes clearly show moral permissiveness. It can therefore be concluded that the distinction between the religiousness and morality of young people is increasing. Young people do not accept all of the moral norms imposed on them by their religion, but instead choose the norms that suit them in specific circumstances. Being attracted to mood-changing substances is just one example of the mentioned discords.

The authors postulate introducing meeting with parents as part of the school's system of preventive programs, during which they will be informed about the significance of factors that may condition young people to use psychoactive drugs. The participation of parents and guardians in the difficult period of their child's growing up and shaping his or her attitudes seem to be key factors protecting youth against undertaking risky activities. What is particularly important seems to be that adults (parents, guardians, and teachers) respect the rules that they require adolescents to follow. Parents and children spending time together, especially conversations during meetings, depending on their character, can either encourage young people to undertake risky behaviors or they can constitute stable protective factors. Children very carefully observer adults. The material with which they enter into adulthood is collected on the basis of observations of important people from their environment, especially parents. ${ }^{39}$ This information also needs to be handed on to parents, or at least they ought to be reminded of it.

\footnotetext{
${ }^{39}$ Albert BANDURA, "Self-efficacy. Toward a Unifying Theory of Behavioral Change," Psychology Review no 2 (1977): 191-215.
} 


\section{BIBLIOGRAPHY}

BANDURA, Albert. "Self-efficacy. Toward a Unifying Theory of Behavioral Change." Psychology Review no 2 (1977): 191-215.

BERger, Peter L. Pytanie o wiarę. Sceptyczna zachęta do chrześcijaństwa [Questions about the Faith. Sceptic Encouragements for Christianity]. Warszawa: Instytut Wydawniczy PAX, 2007.

Boguszewski, Rafał. “(Nie)religijna moralność katolików w Polsce” [(Non)Religious Morality of Catholics in Poland]. Zeszyty Naukowe KUL no 1(57) (2014): 123-139.

Dalgalarrondo, Paulo, Meire A. Soldera, Heleno R.C. Filho, Cleide A.M. Silva, "Religion and Drug Use by Adolescents." Revista Brasileira de Psiquiatria 26, no 2 (2004): 82-90. http://dx.doi.o- rg/10.1590/S1516-44462004000200004.

EngS, Ruth C., Kenneth Mullen. "The Effect of Religion and Religiosity on Drug Use among a Selected Sample of Post Secondary Students in Scotland." Addiction Research 7, no 2 (1999): 149-170. https://doi.org/10.3109/16066 359909004380.

European Monitoring Centre For Drugs And Drug Addiction. European Drug Report 2017: Trends and Developments. Luxembourg: Publications Office of the European Union, 2017.

FernándeZ, María P.L. "El Concepto de Anomia de Durkheim y Las Aportaciones Teóricas Posteriores." Revista de Ciencias Sociales de la Universidad Iberoamericana 4, no 8 (2009): 130-147.

GIDDENS, Anthony. Socjologia [Sociology]. Warszawa: Wydawnictwo Naukowe PWN, 2006.

GoŚCIŃSKI, Grzegorz. Raport o narkotykach i narkomanii $w$ Województwie Podkarpackim w 2016 roku [Report on Drugs and Drug Addiction in the Podkarpackie Voivodeship in 2016]. Rzeszów: Urząd Marszałkowski Województwa Podkarpackiego Departament Ochrony Zdrowia i Polityki Społecznej, 2017. https://www.podkarpackie.pl/index.php/zdrowie/raporty-analizy (accessed: 13.06.2018).

GUS. Trwanie życia w 2015 r. [Life Expectancy in 2015, Statistical Publications]. Warszawa: Zakład Wydawnictw Statystycznych, 2016.

Ismail A., AfFandy H.B., BasiR S.N., AhMAD N. The Internet: One of the Factors Influencing Substance Abuse. https://www.researchgate.net/publication/269223304 (accessed: 26.01.2018).

JARMOCH, Edward. "Religijność indywidualna Polaków." In Kościót i religijność Polaków 19451999 [Individual Religious Beliefs among Poles, in: The Church and Religiousness among Poles 1945-1999], edited by Witold Zdaniewicz, Tadeusz Zembrzuski, 385-405. Warszawa: Instytut Statystyki Kościoła Katolickiego SAC, 2000.

JAROSZYŃSKI, Piotr. "Etyka i religia-opozycja czy dopełnienie?” In U źródeł tożsamości kultury europejskiej [Ethics and Religion, in Opposition or Complementary? in: The Sources of the Identity of European Culture], edited by Tomasz Rakowski, 110-112. Lublin: Lubelska Szkoła Filozofii Chrześcijańskiej KUL, 1994.

JęDrzejko, Mariusz Z. „Zawirowany” świat ponowoczesności [The “Insane” Post-Modern World]. Warszawa-Milanówek: Oficyna Wydawnicza ASPRA-JR, Centrum Profilaktyki Społecznej, 2015.

JEDYNAK, Witold. "Wybrane aspekty przemian religijności i moralności młodzieży polskiej.” In $C z y$ stracone pokolenie? Mtodzież i jej dylematy na początku XXI wieku [Select Aspects of Religious Transformations and Morality among Polish Youth, in: A Lost Generation? Youth and their 
Problems at the Turn of the XXI Century], edited by Piotr Długosz, Hubert Kotarski, Witold Jedynak, 13-24. Rzeszów: Wydawnictwo Uniwersytetu Rzeszowskiego, 2014.

JilohA, Ram Chander. "Social and Cultural Aspects of Drug Abuse in Adolescents." Delhi Psychiatry Journal 12, no 2 (2009): 167-175.

MalczewsKi, Artur. "Młodzież a substancje psychoaktywne.” In Młodzież 2016. Raport z badania sfinansowanego przez. Krajowe Biuro ds. Przeciwdziałania Narkomanii. [Youth and Psychoactive Substances, in: Youth 2016. Report from the study Financed by the National Bureau for Drug Prevention, The CBOS Foundation for Public Opinion Research], 200-225. Warszawa: Fundacja Badania Opinii Społecznej CBOS, 2016.

MARIAŃSKI, Janusz. Młodzież między tradycja i ponowoczesnościq. Wartości moralne w świadomości maturzystów [The Youth, Tradition and Post-Modernity. Moral Values in the Awareness of Graduating High School Youth]. Lublin: Redakcja Wydawnictw KUL, 1995.

MARIAŃSKI, Janusz. Przemiany moralności polskich maturzystów w latach 1994-2000. Studium socjologiczne [Transformations in the Morality of Polish High School Graduates in the Years 1994-2000. A Sociological Study]. Lublin: Wydawnictwo KUL, 2011.

MARIAŃSKI, Janusz. Religia w spoteczeństwie ponowoczesnym. Studium socjologiczne [Religion in Post-Modern Society. A Sociological Study]. Warszawa: Oficyna Naukowa, 2010.

MARIAŃSKI, Janusz. "Kontrowersje wokół relacji religii i moralności-tożsamość czy rozdział" [Controversies Concerning the Relationship between Religion and Morality, One's Identity or Discord?]. Universitas Gedanensis no 1-2 (2009): 16-43.

MARIAŃSKI, Janusz. Kościót w społeczeństwie przemystowym [The Church in the Industrialized World]. Warszawa: Instytut Wydawniczy PAX, 1983.

MARIAŃSKI, Janusz. Matżeństwo i rodzina $w$ świadomości młodzieży maturalnej. Stabilność $i$ zmiana [Marriage and Family in the Awareness of Graduating High School Youth. Stability and Change]. Toruń: Wydawnictwo Adam Marszałek, 2012.

Marsiglia, Flavio F., Stephen Kulis, Tanya Nieri, Monica Parsai. "God Forbid! Substance Use Among Religious and Nonreligious Youth." American Journal of Orthopsychiatry 75, no 4 (2005): 585-598. DOI: 10.1037/0002-9432.75.4.585.

MiteK, Eugeniusz. "Sympatyzowanie młodzieży z osobami zażywającymi narkotyki” [Youth Having Sympathies with People Using Illegal Narcotics]. Perspectiva. Legnickie Studia Teologiczno-Historyczne no 2 (2004): 174-176.

МотүкA, Marek. "Uwarunkowania narkomanii młodzieży: zagrożenia w środowisku rodzinnym i rówieśniczym." In Zagrożenia ładu społecznego oraz bezpieczeństwa narodowego [Determinants of Drug Addiction in Adolescents: Threats in the Family and Peer Environment, in: Threats to Social Order and National Security], edited by Maciej Gitling; Ireneusz Wojaczek, 35-55. Przemyśl: Wydawnictwo Państwowej Wyższej Szkoły Wschodnioeuropejskiej, 2017.

MOTYKA, Marek, Jerzy T. MARCINKOwski. "Rola czasu spędzanego w Internecie w liberalizacji postaw wobec środków psychoaktywnych wśród uczniów przemyskich szkół gimnazjalnych" [The Role of Time Spent on the Internet and the Liberalization of Attitudes Towards Psychoactive Drugs among Junior High School Students]. Problemy Higieny i Epidemiologii no 3 (2014): 737-743.

Osco, Buddi. "Anomie or Alienation? A Self-Exploration of the Roots of Substance Abuse." Human Architecture: Journal of the Sociology of Self-Knowledge 2, no 1 (2003): 105-108.

OssowsKA, Maria. O człowieku, moralności i nauce: miscellanea [On Man, Morality and Science: Miscellanea]. Warszawa: Państwowe Wydawnictwo Naukowe, 1983. 
PAWLIK, Wojciech. "Tożsamość religijna a etyka niezależna—społeczny wymiar dyskursu." In Tożsamości religijne $w$ społeczeństwie polskim. Socjologiczne studium przypadków [Religious Identity and Independent Ethics. The Social Discourse Dimension, in: Religious Identities in Polish Society. Sociological Case Studies], edited by Maria Libiszowska-Żółtkowska, 119-135. Warszawa: Wydawnictwo Delfin, 2009.

PonczeK, Danuta, Iwona Olszowy. "Styl życia młodzieży i jego wpływ na zdrowie” [Youths' Lifestyle and its Impact on Health, "Problems with Hygiene and Epidemiology"]. Problemy Higieny i Epidemiologii no 2 (2012): 260-268.

Possenti, Vittorio. Religia i życie publiczne. Chrześcijaństwo $w$ dobie ponowożytnej [Religion and Public Life. Christianity in the Post-Modern Age]. Warszawa: Instytut Wydawniczy PAX, 2005.

SADOWSKI, Andrzej. "Wschodnie województwa Rzeczypospolitej-uwarunkowania konstruowania kapitału pogranicza" [The Republic of Poland's Eastern Regions: Conditions Shaping the Border Capital]. Konteksty Spoteczne no 2 (2013): 8-17.

SiEMIENOwiCz, Justyna. "Dusza pod narkozą" [The Soul under Narcotics]. Znak no 693 (2013): 6-10.

SROKA, Artur. Teologia narkotyku [Theology of Narcotics]. Warszawa: Wydawnictwo „Eneteia”, 2008.

SzACKI, Jerzy. Historia myśli socjologicznej [History of Sociological Thought]. Warszawa: Wydawnictwo Naukowe PWN, 2007.

The United Nations Office On Drugs And Crime, World Drug Report 2017. Vienna: United Nations Publication, 2017.

Wanat, Wojciech. Narkotyki i narkomania. Odlot donikąd [Narcotics and Drug Addition. Taking Off to Nowhere]. Warszawa: Wydawnictwo „Iskry”, 2006.

ZARĘBA, Sławomir H. W kierunku jakiej religijności? Studia nad katolicyzmem polskiej młodzieży [What Type of Religiousness? Studies on the Catholicism of Polish Youth]. Warszawa: Zakład Wydawnictw Statystycznych, 2008.

ZARĘBA, Sławomir H. Dynamika świadomości religijno-moralnej młodzieży w warunkach przemian ustrojowych w Polsce (1988-1998) [Dynamics of Religious and Moral Awareness of Young People in the Conditions of Political Change in Poland (1988-1998)]. Warszawa: Zakład Wydawnictw Statystycznych, 2003.

ZEMŁo, Mariusz. "Socjologia moralności Marii Ossowskiej i Janusza Mariańskiego. Analiza porównawcza" [Maria Ossowska's and Janusz Mariański's Moral Sociology. A Comparative Analysis]. Roczniki Nauk Społecznych no 2, (2015): 133-159. DOI: http://dx.doi.org/10.18290/rns.2015.7(43).2-12.

ZHAO, Rouhi, Liqun CAO. "Social Change and Anomie: A Cross-National Study." Social Forces 88, no 3 (2010): 1209-1229. DOI: 10.1353/sof.0.0312.

ZIELIŃski, Michał. Religia a moralność [Religion and Morality]. Toruń: Wydawnictwo Adam Marszałek, 2000.

\section{Translated by Jan Kobytecki}

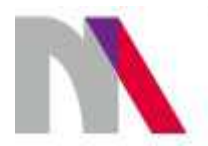

The preparation of the English version of Roczniki Teologiczne (Annals of Theology) and its publication in electronic databases was financed under contract no. 836/P-DUN/2018 from the resources of the Minister of Science and Higher Education for the popularization of science. 